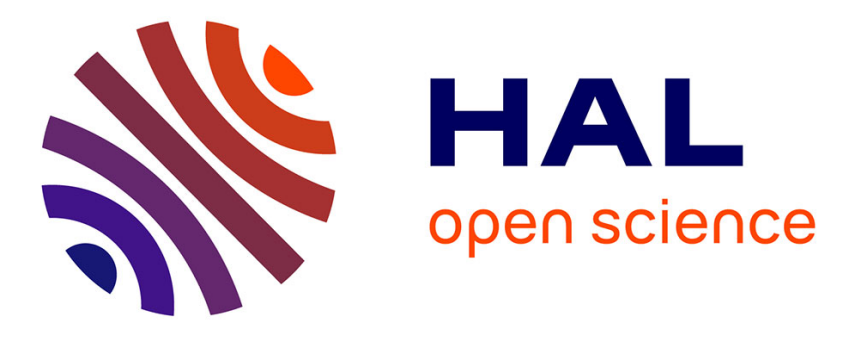

\title{
Synthesis and microstructure of cobalt ferrite nanoparticles
}

Lilia Ajroudi, Sylvie Villain, V. Madigou, N. Mliki, Christine Leroux

\section{To cite this version:}

Lilia Ajroudi, Sylvie Villain, V. Madigou, N. Mliki, Christine Leroux. Synthesis and microstructure of cobalt ferrite nanoparticles. Journal of Crystal Growth, 2010, 312, pp.2465. 10.1016/j.jcrysgro.2010.05.024 . hal-01027558

\section{HAL Id: hal-01027558 \\ https://hal-univ-tln.archives-ouvertes.fr/hal-01027558}

Submitted on 22 Jul 2014

HAL is a multi-disciplinary open access archive for the deposit and dissemination of scientific research documents, whether they are published or not. The documents may come from teaching and research institutions in France or abroad, or from public or private research centers.
L'archive ouverte pluridisciplinaire HAL, est destinée au dépôt et à la diffusion de documents scientifiques de niveau recherche, publiés ou non, émanant des établissements d'enseignement et de recherche français ou étrangers, des laboratoires publics ou privés. 


\title{
Synthesis and microstructure of cobalt ferrite nanoparticles
}

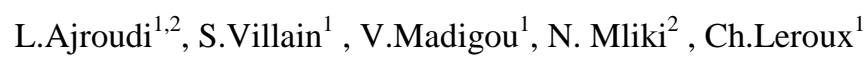 \\ 1. IM2NP (UMR-CNRS 6242), Université du Sud Toulon-Var (USTV), Bât.R, B.P.20132, 83957 La Garde \\ Cedex, France
}

2. LMOP, Physics Department, Faculty of Sciences of Tunis, 2092 Tunis, Tunisia

\begin{abstract}
Cobalt ferrites $\left(\mathrm{Co}_{\mathrm{x}} \mathrm{Fe}_{3-\mathrm{x}} \mathrm{O}_{4}\right)$ nanoparticles with various compositions were synthesized by a new non-aqueous synthesis method. The cobalt ferrites were characterized by $\mathrm{X}$-rays diffraction, and transmission electron microscopy coupled with energy dispersive spectroscopy. The nanoparticles are highly crystallized, with a homogeneous chemical composition. The particle size varies from $4 \mathrm{~nm}$ up to $7.5 \mathrm{~nm}$, depending on the cobalt content. The smallest particles, with a size of $4 \mathrm{~nm}$, are obtained for high cobalt content. These particles have also the highest micro-structural strain. Catalytic measurements were realized using Fourier Transform Infrared Spectroscopy. The lowest activation energy and the highest conversion rate are obtained for $\mathrm{Co}_{1.8} \mathrm{Fe}_{2.4} \mathrm{O}_{4}$, in the $400-500{ }^{\circ} \mathrm{C}$ temperature range.
\end{abstract}

Corresponding author: Christine Leroux, leroux@univ-tln.fr

Université du Sud Toulon Var, USTV, IM2NP, CNRS UMR 6242

Bât. R, BP 20132, F-83957 La Garde Cedex, France

tel 0033 (0)4 941423 12, Fax: 0033 (0)4 94142168

\section{Introduction}

Cobalt ferrites have already many applications, mainly because of their original magnetic properties [1-3], associated to low cost of production, chemical stability and bio compatibility. Nanoparticles of cobalt ferrites are used for example in ferrofluid technology [4], biosensors [5] and medical diagnostic [6]. In addition, a new domain for the use of spinel ferrites has opened recently, namely catalysis [7, 8]. In fact, ferrites are already effective catalysts for various processes like treatment of exhaust gases [9], oxidation of toluene [10] or propane [11], gas sensing [12]. Nickel ferrites showed good catalytic properties in the 
presence of reducing gas such as $\mathrm{CO}$ [13], and cobalt ferrites were tested for the Fischer Tropsch reaction [14].

Many techniques have been developed for the synthesis of $\mathrm{CoFe}_{2} \mathrm{O}_{4}$ nanoparticles during the last years. The most frequent one is the co-precipitation method [15-17], which can be associated to mechanical milling [18]. The synthesis can also be performed under hydrothermal condition $[19,20]$. Nanoparticles of cobalt ferrites were also obtained by simple ball milling [21], or combustion method [22]. Soft chemical syntheses, like sol gel [23, 24], or more recently a glycothermal process [25] were developed in order to elaborate very small superparamagnetic nanoparticles of cobalt ferrites. The profusion of syntheses in the literature is explained by the dependence of the nanoferrites magnetic properties on the preparation methods [26].

In this work, we have developed a simple one pot solvothermal synthesis method to obtain cobalt ferrites nanoparticles with the general formula $\mathrm{Co}_{\mathrm{x}} \mathrm{Fe}_{3-\mathrm{x}} \mathrm{O}_{4}$ for $0.5<\mathrm{x}<2$, according to the phase diagram of the Fe-Co-O system [27]. The nanoparticles of cobalt ferrites were synthesized by the so called "benzyl alcohol route", which is a surfactant free non aqueous synthesis, derived from the work of Pinna [28]. This benzyl alcohol route was up to now mainly used to synthesize simple oxides like $\mathrm{Fe}_{3} \mathrm{O}_{4}, \mathrm{VO}_{2}, \mathrm{CeO}_{2}, \mathrm{MnO}[28,29]$. It is then a one step synthesis method, in which the metal precursors are dissolved in benzyl alcohol, the solution put in an autoclave, and heated. This way to do is efficient with a lot of precursors like metal alkoxides, acetylacetonates or acetates. On the contrary, in case of multi metal oxides, the nature of the precursors and the way one dissolves the precursors play an important role. The benzyl alcohol route was then successful only using metal and metal alkoxyde [29,30], which means preparation in a glove box to prevent oxidation of the metal and special care in dissolving the precursors. Our work is the first report of the successful synthesis of a highly crystalline multi metal oxide by simply dissolving two acetylacetonates in benzyl alcohol. Nanoparticles of cobalt ferrites, were already obtained by another one pot non aqueous process using cobalt and iron acetates in diethylene glycol, and heating the solution, but then the obtained nanoparticles were poorly crystallized [31].

We were interested in testing the catalytic properties of these nanoparticles, for further applications in gas sensors. The size distribution, the dispersion, and the chemical composition of the nanoparticles were studied by Transmission Electron Microscopy (TEM), coupled with Energy Dispersive Spectroscopy (EDS) . High Resolution Electron Microscopy (HREM) gave information on the faceting of the particles, and more generally, on their shape. The cell parameter of the spinel phases was determined by X-rays diffraction. Catalytic properties of 
the nanopowders in presence of methane were studied by Fourier Transform Infrared (FTIR) Spectrometry of outgoing gases from the reactor cell.

\section{Experimental procedures}

\subsection{Synthesis of $\mathrm{Co}_{\mathrm{x}} \mathrm{Fe}_{3-\mathrm{x}} \mathrm{O}_{4}$ nanoparticles}

The nanoparticules of cobalt ferrite were synthesized by a new non aqueous route, derived from the work of Pinna [28] concerning magnetite nanoparticles. Cobalt (II) 2,4pentanedionate and iron (III) acetylacetonate, characterized by the total mass of precursors $\mathrm{m}_{\mathrm{p}}=0.1 \mathrm{~g}, 0.5 \mathrm{~g}, 1 \mathrm{~g}$, and $5 \mathrm{~g}$, were dissolved in benzyl alcohol. The relative proportion of both precursors was chosen in order to obtain different nominal composition $\mathrm{Co}_{0.6} \mathrm{Fe}_{2.4} \mathrm{O}_{4}$, $\mathrm{Co}_{1} \mathrm{Fe}_{2} \mathrm{O}_{4}, \mathrm{Co}_{1.2} \mathrm{Fe}_{1.8} \mathrm{O}_{4}$ and $\mathrm{Co}_{1.8} \mathrm{Fe}_{1.2} \mathrm{O}_{4}$ referred respectively as $\mathrm{x}=0.6, \mathrm{x}=1, \mathrm{x}=1.2$ and $\mathrm{x}$ $=1.8$. The solution was then stirred for 4 hours, poured into a $45 \mathrm{ml}$ teflon cup, which was sealed into a steel autoclave, and heated in a furnace at $175^{\circ} \mathrm{C}$ for 48 hours. After cooling, the suspension was several times washed with ethanol and dichloromethane, sonicated and centrifuged, in order to remove the excess of solvent. A black powder was obtained after a final drying at $80{ }^{\circ} \mathrm{C}$. The whole procedure of washing and centrifugation was done until no more solvent could be extracted. The mass of cobalt ferrites obtained with low amount of precursors was not sufficient for further experiments, and physical properties of the nanoparticles were studied on powders obtained with $5 \mathrm{~g}$ of precursors, corresponding to $1 \mathrm{~g}$ of final cobalt ferrite powder.

\subsection{Structural characterization}

Morphologies, crystal sizes and chemical compositions of the nanoparticles were determined by TEM, coupled with EDS, using a Tecnai $\mathrm{G}^{2} 200 \mathrm{kV}$ with a $\mathrm{LaB}_{6}$ source and a point to point resolution of $0.25 \mathrm{~nm}$. Images were recorded using a $1 \mathrm{~K}$ x $1 \mathrm{~K}$ Slow Scan CCD camera. The statistical study on particle size was carried on over 500 particles for one composition. EDS analyses were performed in nanoprobe mode, with a spot size of $7 \mathrm{~nm}$, thus on a single particle. On the contrary, several particles were analysed together in the microprobe mode, with a spot size of $100 \mathrm{~nm}$.

The nanopowders were also characterized by X-rays diffraction. The diagrams were recorded in a classical $\theta-2 \theta$ angles coupled mode, on a Siemens-Bruker D5000 diffractometer, operating with a copper X-rays source and equipped with a back monochromator, to avoid fluorescence. The diagrams were collected with a step of $0.04^{\circ}$, a time of 20 s per step, over a 
$2 \theta$ range from 15 to $115^{\circ}$. Information about cell parameters, crystal sizes and microdeformations were extracted using the whole pattern fitting Powdercell software.

\subsection{FTIR spectroscopy}

Powders, placed in a heated cell built of porous $\mathrm{ZrO}_{2}$ in a steel tube, were exposed to a slow continuous flow $\left(10 \mathrm{~cm}^{3} \cdot \mathrm{min}^{-1}\right)$ of air- $\mathrm{CH}_{4}$ gas, and outgoing gases were analysed by FTIR spectroscopy (Unicam-Mattson spectrometer) [32]. The catalytic conversion of $\mathrm{CH}_{4}$ leads to $\mathrm{CO}_{2}$ and $\mathrm{H}_{2} \mathrm{O}$, via the classical combustion reaction $\mathrm{CH}_{4}+2 \mathrm{O}_{2} \rightarrow \mathrm{CO}_{2}+2 \mathrm{H}_{2} \mathrm{O}$. Thus, we related the catalytic efficiency of one sample to the detected amount of $\mathrm{CO}_{2}$, hence to the $\mathrm{CO}_{2}$ absorption peak intensity I ( $\mathrm{t}$ ) in the FTIR spectra. More precisely, as there is a continuous flow of $\mathrm{CH}_{4}$, a flow of $\mathrm{CO}_{2}, \frac{\mathrm{d}\left[\mathrm{CO}_{2}\right]}{\mathrm{dt}}(\mathrm{t})$, is produced when the reaction occurs, and the intensity of the $\mathrm{CO}_{2}$ absorption peak in one spectrum corresponds to the sum of $\frac{\mathrm{d}\left[\mathrm{CO}_{2}\right]}{\mathrm{dt}}(\mathrm{t})$ over the acquisition time $\tau$ of the spectrum. Assuming a continuous variation of $\mathrm{CO}_{2}$ flow during the acquisition time $\tau, \mathrm{I}(\mathrm{t})$ can be considered proportional to the mean value of $\frac{\mathrm{d}\left[\mathrm{CO}_{2}\right]}{\mathrm{dt}}(\mathrm{t})$ over $\tau$. For the different samples, the same amount of powder $(0.3 \mathrm{~g})$ was used. Different $\mathrm{CH}_{4}$ concentrations in air (625 ppm, $\left.1250 \mathrm{ppm}, 2500 \mathrm{ppm}\right)$ fixed by mass flow controllers and different temperatures were tested $\left(400{ }^{\circ} \mathrm{C}, 450{ }^{\circ} \mathrm{C}\right.$ and $\left.500{ }^{\circ} \mathrm{C}\right)$. The FTIR spectra of the outgoing gases were recorded every $30 \mathrm{~s}$, with a recording time of $12 \mathrm{~s}$. The initial time $\mathrm{t}=0 \mathrm{~s}$ corresponds to the moment where the $\mathrm{CH}_{4}$ is injected.

\section{Results and discussion}

\subsection{Structure, morphology, chemical composition}

Whatever the composition of the cobalt ferrites powders, and the initial amount of precursors put in benzyl alcohol, we observed by TEM well crystallized and well dispersed nanoparticles (Fig. 1). 


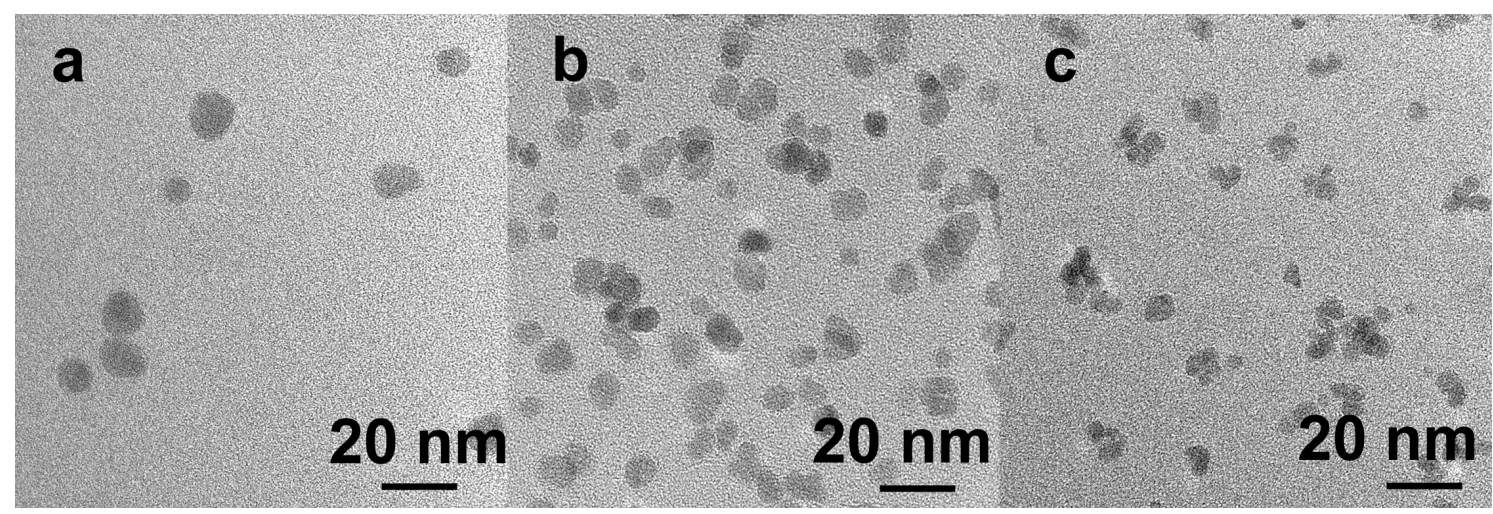

Figure 1: TEM images of well dispersed $\mathrm{Co}_{x} \mathrm{Fe}_{3-x} \mathrm{O}_{4}$ nanoparticles, for different cobalt amount $x$ and different quantity of precursors $m_{p}$ : a) $x=0.6, m_{p}=5 g$; b) $x=1, m_{p}=1 g$; c) $x=1.8, m_{p}=1 g$.

The size distribution of the particles is shown in Fig.2, the mean size and the standard deviation are given in Table 1.
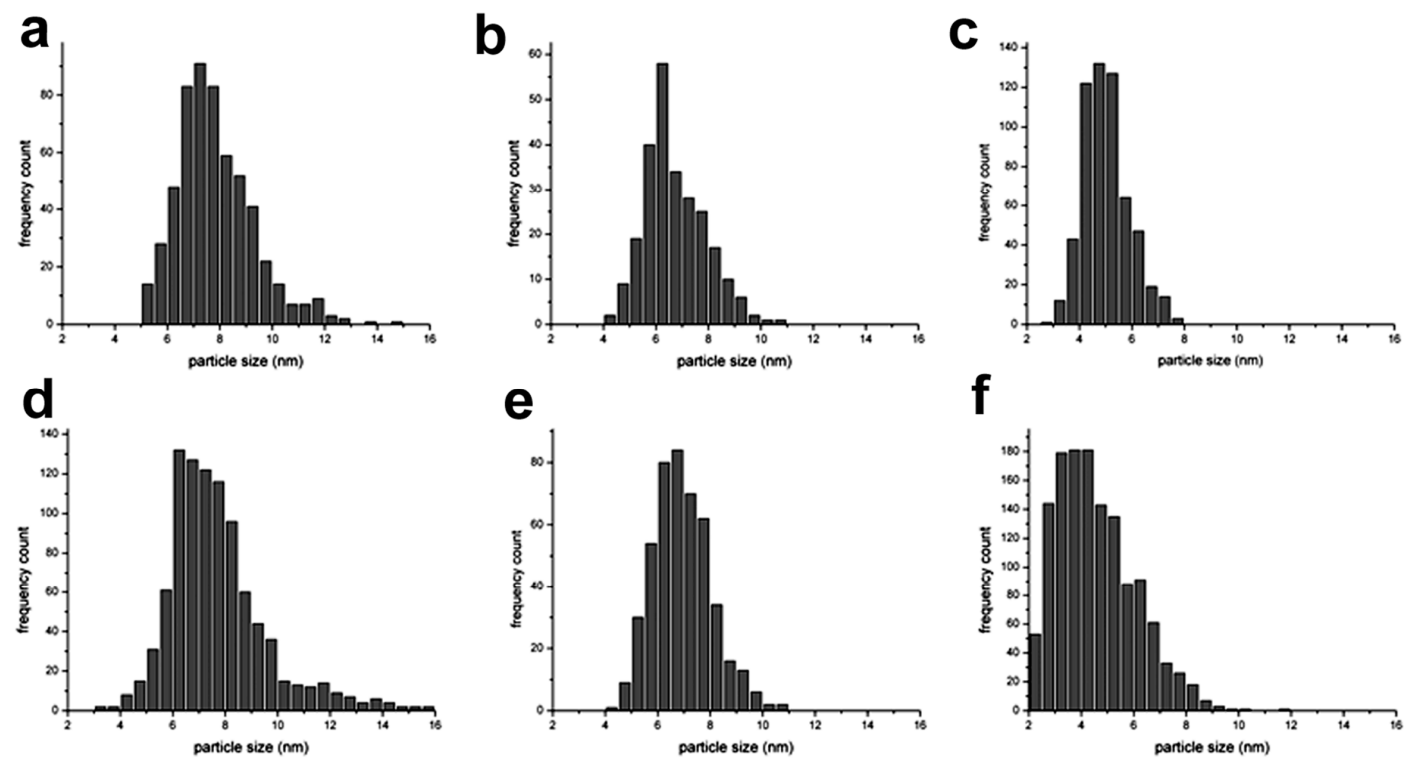

Figure 2: Size distribution of the $\mathrm{Co}_{x} \mathrm{Fe}_{3-x} \mathrm{O}_{4}$ nanoparticles, for different cobalt amount $x$ and different quantity of precursor $m_{p} ; x=0.6, x=1$ and $x=1.8$, prepared with $m_{p}=1 g(a, b, c)$ and $m_{p}=5 g(d, e, f)$.

The mean size of the nanoparticles decreases slightly with increasing cobalt amount $\mathrm{x}$ in $\mathrm{Co}_{\mathrm{x}} \mathrm{Fe}_{3-\mathrm{x}} \mathrm{O}_{4}$, and the smallest ones (4 nm, Fig. 2) are obtained for the highest cobalt amount, $\mathrm{x}=1.8$. Measurements of the particles sizes were performed with an error of $0.5 \mathrm{~nm}$. Thus, the slight decrease of the mean size with $\mathrm{m}_{\mathrm{p}}$, the precursors mass, for a given cobalt amount, is not significant. The size distribution of the particles is somewhat influenced by the initial amount of precursors, with broader size distribution for high precursor amount (Fig. 2), due to the presence of particles with sizes around 12-16 $\mathrm{nm}$. 


\begin{tabular}{lll}
\hline$(\mathrm{x} ; \mathrm{mp})$ & Particle size $(\mathrm{nm})$ & Deviation \\
\hline & mean & $\sigma(\mathrm{nm})$ \\
\cline { 2 - 3 }$(0.6 ; 1 \mathrm{~g})$ & 7.5 & 1.5 \\
$(0.6 ; 5 \mathrm{~g})$ & 7 & 2 \\
$(1 ; 1 \mathrm{~g})$ & 7 & 1 \\
$(1 ; 5 \mathrm{~g})$ & 6.5 & 1 \\
$(1.8 ; 1 \mathrm{~g})$ & 5 & 1 \\
$(1.8 ; 5 \mathrm{~g})$ & 4 & 1.5 \\
\hline
\end{tabular}

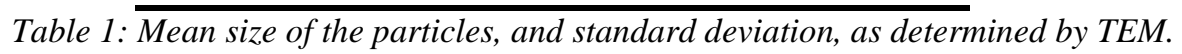

High resolution images showed that these bigger particles are in fact produced during a coalescence phenomenon in powders elaborated with $m_{p}=5$ g. Fig. 3 is one example of two "spherical" nanoparticles building one crystallite, with classical (111) twin boundaries.

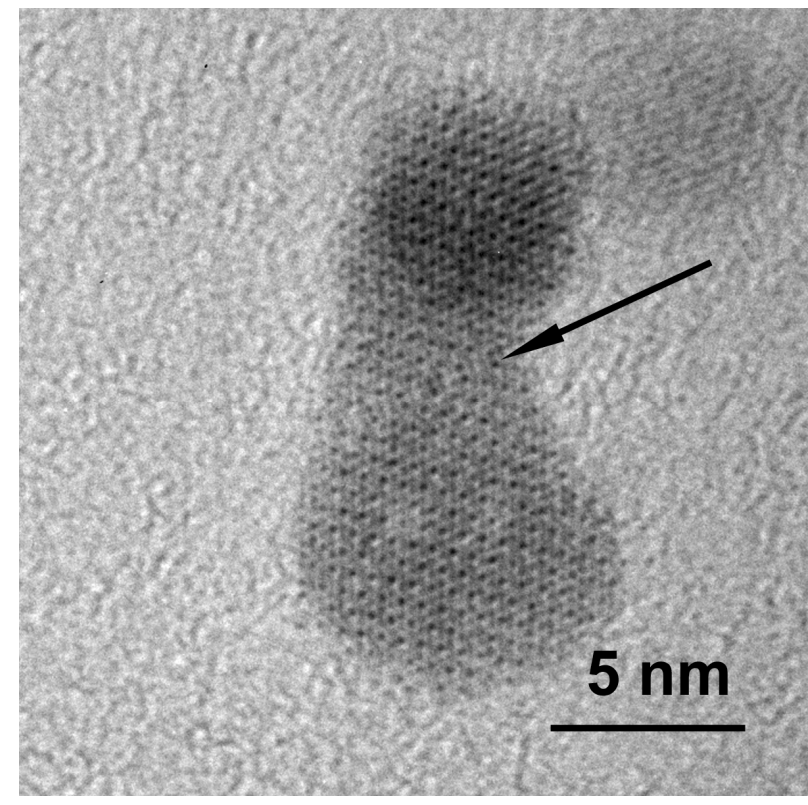

Figure 3: HREM image of one $\mathrm{Co}_{1} \mathrm{Fe}_{2} \mathrm{O}_{4}$ particle oriented with a zone axis [110], resulting from the coalescence of two particles (the twin boundary is indicated by an arrow).

The relative amount of cobalt and iron influences the morphology of the particles. Particles with a nominal composition near $\mathrm{CoFe}_{2} \mathrm{O}_{4}$, are almost spherical (Fig. 4a, $\mathrm{x}=0.6$ ), but clearly more facetted for $\mathrm{x}=1$ (Fig. 4b). For composition near $\mathrm{Co}_{2} \mathrm{FeO}_{4}$, the shape of the particle is very irregular (Fig. 4c). Concerning the crystallographic structure of the nanoparticles, whatever the composition, the Fast Fourier Transform (FFT) realized on HREM images showed that each particle was monocrystalline, with the expected spinel structure (see Fast Fourier Transform in Fig. 4). 


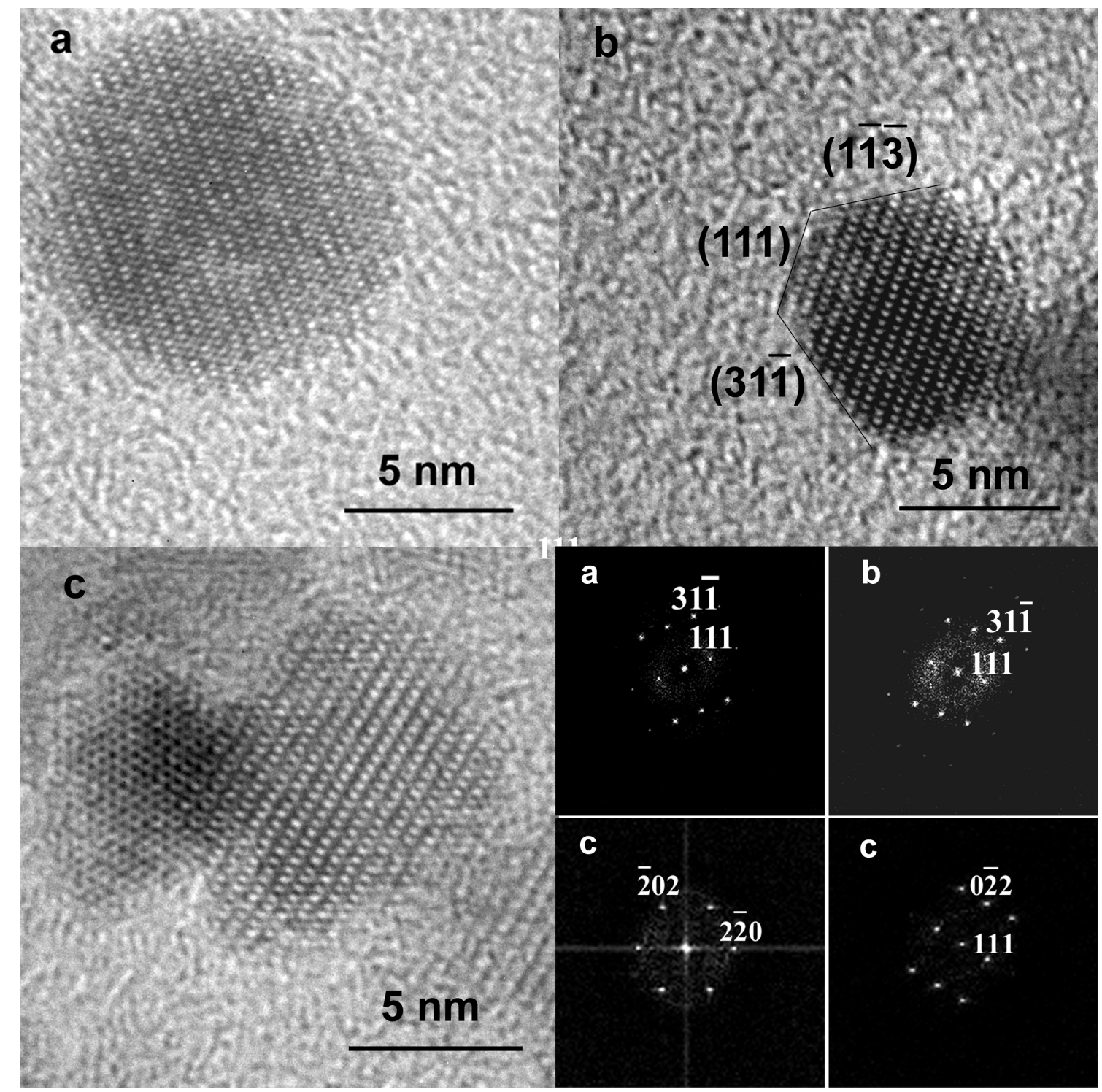

Figure 4: HREM images of nanoparticles, a) nearly spherical $\mathrm{Co}_{0.6} \mathrm{Fe}_{2.4} \mathrm{O}_{4}$ nanoparticle, oriented [1 $\overline{2} 1$ ] (see FFT a). b) $\mathrm{CoFe}_{2} \mathrm{O}_{4}$ nanoparticle, oriented [1 $\overline{2} 1$ ], with (113) and (111) facets (see FFT b). c) $\mathrm{Two} \mathrm{Co}_{1.8} \mathrm{Fe}_{1.2} \mathrm{O}_{4}$ nanoparticles with irregular shapes oriented [ $\overline{2} 11]$ and [111] (see FFT c).

The chemical composition of the powders was determined by EDS analyses. In the microprobe mode, up to 10 particles were analysed together. Results are summarised in Table 2. The measured compositions are in agreement with the nominal composition, excepted for one powder $\left(\mathrm{x}=1.8 ; \mathrm{m}_{\mathrm{p}}=1 \mathrm{~g}\right)$. The standard deviation is low, within the experimental error of EDS analyses, commonly estimated to be 1-2 at. \%. This indicates a homogeneous composition of the powders. For some compositions, single particles were analysed, in the so called nanoprobe mode, with a probe size of $7 \mathrm{~nm}$. Both modes led to the same mean composition for the different powders, but with a higher dispersion of the nanoprobe results for the powder with cobalt amount around $\mathrm{x}=1.8$. In that case, composition fluctuations from 
$\mathrm{x}=1.6$ to $\mathrm{x}=1.8$ could be observed. Let us remember that $\mathrm{Fe}_{3} \mathrm{O}_{4}$ has an inverse spinel structure and $\mathrm{Co}_{3} \mathrm{O}_{4}$ a normal spinel one. With increasing $\mathrm{x}$, cobalt ferrites $\mathrm{Co}_{\mathrm{x}} \mathrm{Fe}_{3-\mathrm{x}} \mathrm{O}_{4}$ change from the inverse spinel structure to the normal spinel structure [27]. Around $x=2$, a spinodal decomposition for cobalt ferrites annealed at high temperatures was evidenced [33,34], with compositions fluctuations from $\mathrm{x}=1.1$ to 2.7. The HREM characterization of the nanoparticles, coupled with EDS analyses, showed that this decomposition did not occurred in our samples.

\begin{tabular}{lll}
\hline$\left(\mathrm{x} ; \mathrm{m}_{\mathrm{p}}\right)$ nominal & \multicolumn{2}{c}{$\mathrm{x}$ measured } \\
\hline & mean & $\sigma$ \\
\cline { 2 - 3 }$(0.6 ; 1 \mathrm{~g})$ & 0.58 & 0.02 \\
$(0.6 ; 5 \mathrm{~g})$ & 0.56 & 0.02 \\
$(1 ; 1 \mathrm{~g})$ & 0.95 & 0.03 \\
$(1 ; 5 \mathrm{~g})$ & 0.99 & 0.01 \\
$(1.2 ; 1 \mathrm{~g})$ & 1.18 & 0.02 \\
$(1.8 ; 1 \mathrm{~g})$ & 1.61 & 0.02 \\
$(1.8 ; 5 \mathrm{~g})$ & 1.76 & 0.04
\end{tabular}

Table 2: Mean composition (with the standard deviation) of the $\mathrm{Co}_{x} \mathrm{Fe}_{3-x} \mathrm{O}_{4}$ powders, obtained by EDS analyses

The X-rays diagrams obtained on $\mathrm{Co}_{\mathrm{x}} \mathrm{Fe}_{3-\mathrm{x}} \mathrm{O}_{4}$ nanopowders, for 4 different compositions could all be indexed in a single spinel cubic structure. One diagram is shown Fig. 5.

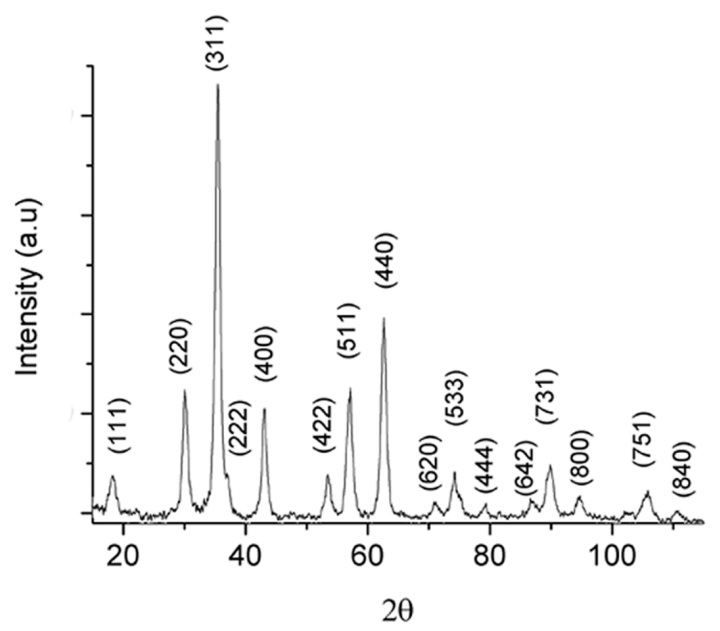

Figure 5: X-rays diagram of a $\mathrm{Co}_{0.6} \mathrm{Fe}_{2.4} \mathrm{O}_{4}$ powder, corresponding to the expected spinel structure. 
For each composition, the whole diagram was fitted with Powdercell, using the inverse spinel $\mathrm{CoFe}_{2} \mathrm{O}_{4}$ structure, and pseudo Voigt functions. As scattering factors for cobalt and iron are nearly the same, no refinement of the occupation of the different atomic sites was attempted. The goodness of fit $\mathrm{G}=\mathrm{R}_{\mathrm{wp}} / \mathrm{R}_{\exp }$ was around 1.2 for the different fitted diagrams. Zero shift, cell parameters, and Full Half Width at Half Maximum (FHWM) or breadth $\beta$ were obtained. The values for cell parameters, grain size, and crystallographic distortions are collected in Table 3. The lattice parameter varies peculiarly with the cobalt concentration $\mathrm{x}$ of the ferrites, with a maximum value attained for $\mathrm{x}=1(\mathrm{a}=0.84002 \mathrm{~nm})$, and a minimum value for $\mathrm{x}=1.8(\mathrm{a}=0.83826 \mathrm{~nm})($ Fig 6$)$.

\begin{tabular}{llll}
\hline $\mathrm{x}$ & $\mathrm{a}(\mathrm{nm})$ & $\mathrm{D}(\mathrm{nm})$ & $\varepsilon$ \\
\hline 0.6 & 0.83857 & 10.5 & 0.011 \\
1 & 0.84002 & 10 & 0.018 \\
1.2 & 0.83940 & 10 & 0.020 \\
1.8 & 0.83826 & 8.5 & 0.028 \\
\hline
\end{tabular}

Table 3 : Cell parameters, crystallite size and distortion, as determined by $X$ rays diffraction.

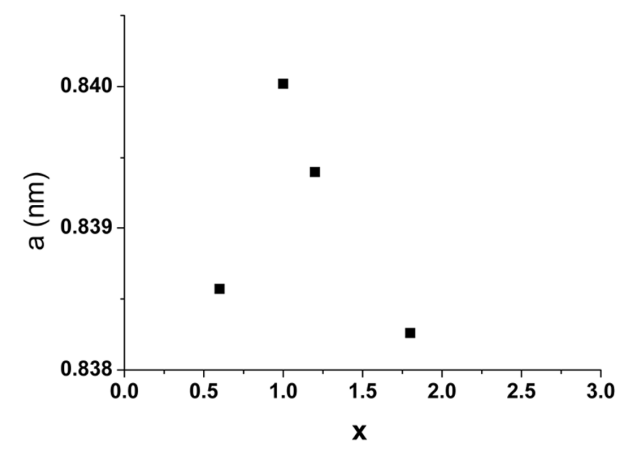

Fig.6: Evolution of the cell parameter a, with $x$ in $\mathrm{Co}_{x} \mathrm{Fe}_{3-x} \mathrm{O}_{4}$ powders.

A similar variation of the cell parameter for cobalt ferrites with $\mathrm{x}<1$ and $\mathrm{x}>1$ was already observed by [35], and linked to the variation of the $\mathrm{Fe}^{3+}, \mathrm{Fe}^{2+}, \mathrm{Co}^{3+}$ and $\mathrm{Co}^{2+}$ repartition on tetrahedral and octahedral sites. Let us remember that in pure $\mathrm{Fe}_{3} \mathrm{O}_{4}$ inverse spinel structure, all the tetrahedral sites A (8a) are occupied by $\mathrm{Fe}^{3+}$, as octahedral sites $\mathrm{B}$ (16d) are occupied by $\mathrm{Fe}^{3+}$ and $\mathrm{Fe}^{2+}$ in equal proportion. On the contrary, for $\mathrm{Co}_{3} \mathrm{O}_{4}$, octahedral sites are occupied by $\mathrm{Co}^{3+}$ and tetrahedral sites by $\mathrm{Co}^{2+}$ (normal spinel). Thus, the determination of the precise repartition of the different cations in cobalt ferrites gave rise to a rich literature, among them $[33,36]$. It is now admitted that for low cobalt content, $\mathrm{Co}^{2+}$ replaces $\mathrm{Fe}^{2+}$ on octahedral sites, but also $\mathrm{Fe}^{3+}$ on tetrahedral sites, leading to an increase of the cell parameter with increasing $\mathrm{x}$. The decrease of the cell parameter, when $\mathrm{x}$ varies from 1 to 3 , is explained by an increasing substitution of $\mathrm{Fe}^{3+}$ by $\mathrm{Co}^{3+}$ in octahedral sites. The breadth $\beta$ of pseudo Voigt functions is usually linked to the size $\mathrm{D}$ of the diffracting domains and to the crystallographic distortion $\varepsilon$ by the relation: $\left(\frac{\beta^{*}}{\mathrm{~d}^{*}}\right)^{2}=\frac{1}{\mathrm{D}} \frac{\beta^{*}}{\mathrm{~d}^{*}}+\left(\frac{\varepsilon}{2}\right)^{2}$, with $\beta^{*}=\frac{\beta \cos \theta}{\lambda}$ and 
$\mathrm{d}^{*}=\frac{2 \sin \theta}{\lambda}$, where $\lambda$ is the wavelength of the incident $\mathrm{X}$-rays, $\theta$ is the diffraction angle. Thus, using Halder-Wagner-Langford (HWL) plots, with $\left(\frac{\beta^{*}}{\mathrm{~d}^{*}}\right)^{2}$ drawn as a function of $\frac{\beta^{*}}{\mathrm{~d}^{2}}$, D and $\varepsilon$ could be deduced. The HWL plots showed a slight decrease of the size of the nanoparticles and an increase of the crystallographic distortion, for increasing cobalt amount (Table 3).

\subsection{Catalytic activity}

The kinetics of the $\mathrm{CH}_{4}$ conversion followed the same scheme, for all the tested samples, and for the different $\mathrm{CH}_{4}$ concentration in the temperature range $400-500{ }^{\circ} \mathrm{C}$. The conversion reaction started after a given time, and the conversion rate increased until equilibrium (constant conversion rate) was attained. This constant conversion rate was maintained over more than one hour. Fig. 7 is an example of this evolution. The experimental curves were fitted with different sigmoid curves, and the Boltzmann function, $I=I_{\text {sat }}\left(1-\frac{1}{1+e^{2\left(\frac{t-t_{0}}{\Delta t}-1\right)}}\right)$ was retained as leading to the best fits (chi-square test).

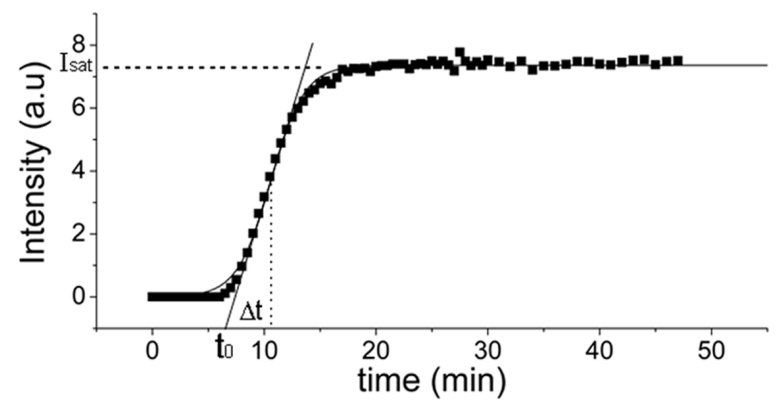

Figure 7: One example of the conversion kinetic of $\mathrm{CH}_{4}$ into $\mathrm{CO}_{2}$, obtained at $450^{\circ} \mathrm{C}$, with $\mathrm{Co}_{1.8} \mathrm{Fe}_{1.2} \mathrm{O}_{4}$ as catalytic powder, under $1250 \mathrm{ppm} \mathrm{CH}_{4}$ in air. $t_{0}$ corresponds to the time at which the slope of the curve at $I_{\text {sat }} / 2$ intercept $I=0$ and $\Delta t$ is the time delay between $I=0$ and $I_{\text {sat }} / 2$.

Full methane conversion rate was obtained at $500{ }^{\circ} \mathrm{C}$ for the different cobalt ferrites and for various $\mathrm{CH}_{4}$ concentrations. The $\mathrm{I}_{\text {sat }}$ values, corresponding to constant conversion rate, were normalized to the highest $\mathrm{I}_{\text {sat }}$ value, which correspond to $100 \% \mathrm{CH}_{4}$ conversion rate (see Fig.8). The highest conversion rate at a given temperature is obtained for $\mathrm{x}=1.8$, the powder with the smallest particle size. The powders with $\mathrm{x}=0.6$ and $\mathrm{x}=1$ have comparable 
conversion rates excepted for high concentration of $\mathrm{CH}_{4}$ for which the cobalt ferrite powder with $\mathrm{x}=0.6$ shows a slightly better conversion rate than for the powder with $\mathrm{x}=1$.

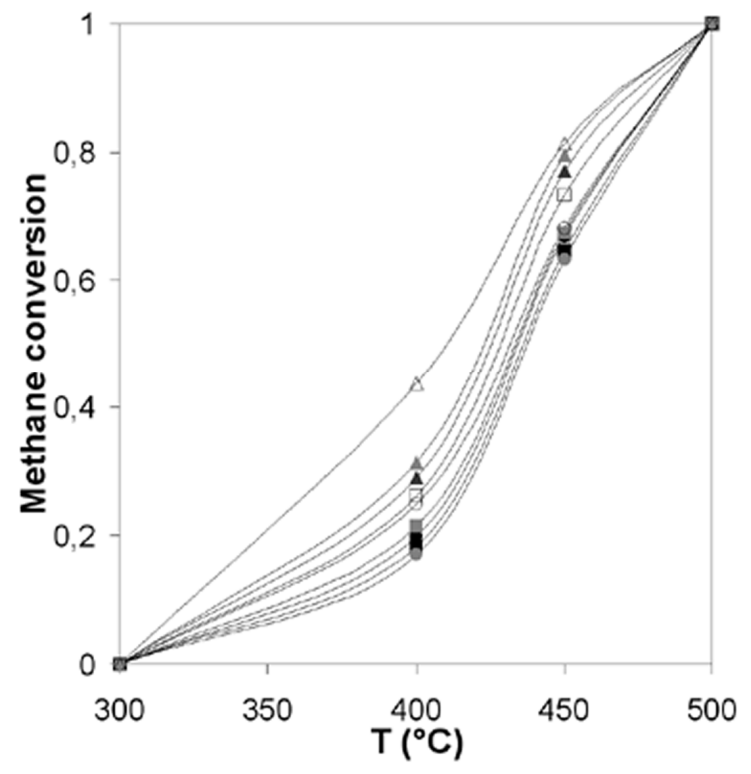

Figure 8: Methane conversion rate, plotted versus temperature, for different $\mathrm{Co}_{x} \mathrm{Fe}_{3-\mathrm{x}} \mathrm{O}_{4}$ powders (x=0.6 O; $x=1 \square ; x=1.8 \Delta$ ) and different $\mathrm{CH}_{4}$ concentrations (2500 ppm in black; 1250 ppm in gray; 625 ppm in white)

The nanoparticles $\mathrm{Co}_{1.8} \mathrm{Fe}_{1.2} \mathrm{O}_{4}$ are the smallest ones from the tested $\mathrm{Co}_{\mathrm{x}} \mathrm{Fe}_{3-\mathrm{x}} \mathrm{O}_{4}$ nanopowders, and with the most irregular exposed surfaces, thus correspond to the highest exposed surface. $\mathrm{Co}_{0.6} \mathrm{Fe}_{2.4} \mathrm{O}_{4}$ and $\mathrm{Co}_{1} \mathrm{Fe}_{2} \mathrm{O}_{4}$ have nearly the same size and the same spherical shape. It is well known that the efficiency of the catalytic conversion increases with the amount of exposed surface, the nature of the exposed cation sites, and the number and type of defects at the surface [37-39]. A relationship between particle size and catalytic activity was recently evidenced in the case of $\mathrm{CoFe}_{2} \mathrm{O}_{4}$ nanoparticles [40], thus for only one composition $\mathrm{x}$ $=1$. Evans et al. [40] showed that a increase of the particle size induces a significant lowering of the conversion rate at a given temperature; the variation of methane conversion rate at a given temperature, for a size variation of the particles from 6 to $8 \mathrm{~nm}$, is around 10 to $15 \%$. We observed bigger variations of the conversion rate, around 20 to $25 \%$, indicating that the size effect is not the only one affecting the conversion rate. By comparing the conversion rate for $\mathrm{x}=0.6$ and $\mathrm{x}=1$, it appears that vacancies and cation distribution play a role in the catalytic reaction. Indeed, nanoparticles with $x=0.6$ and $x=1$ have nearly the same size and shape, but differ in their composition, $\mathrm{x}=1$ corresponding to the stoechiometric composition, thus to the particles with the less vacancies. More information can be obtained about the mechanism of the reaction which governs the conversion of $\mathrm{CH}_{4}$ into $\mathrm{CO}_{2}$ by considering the 
apparent activation energy of the process. When drawing the saturation values as Arrhenius plots, $\operatorname{Ln}\left(I_{s a t}\right)=\operatorname{Ln} A-\frac{E}{k T}$, one obtained linear plots. The apparent activation energies as well as the pre-exponential factor LnA, deduced from linear regression, are listed in Table 4.

\begin{tabular}{cccc}
\hline x in $\mathrm{Co}_{x} \mathrm{Fe}_{3-x} \mathrm{O}_{4}$ & $\begin{array}{c}\mathrm{CH}_{4} \text { concentration } \\
(\mathrm{ppm})\end{array}$ & $E_{a}(\mathrm{eV})$ & $\mathrm{LnA}$ \\
\hline 0.6 & 625 & 0.63 & 11.06 \\
1 & & 0.61 & 10.77 \\
1.8 & & 0.37 & 7.32 \\
0.6 & & 0.80 & 14.26 \\
1 & 1250 & 0.69 & 12.59 \\
1.8 & & 0.53 & 10.23 \\
& & & 13.86 \\
1 & & 0.73 & 14.21 \\
1.8 & & 0.77 & 11.31 \\
\hline
\end{tabular}

Table 4: Apparent activation energy $E_{a}(\mathrm{eV})$, and pre-exponential factor LnA, for different compositions $x$ of the $\mathrm{Co}_{x} \mathrm{Fe}_{3-x} \mathrm{O}_{4}$ powders and for three different $\mathrm{CH}_{4}$ concentration in air (625 ppm, $1250 \mathrm{ppm}, 2500 \mathrm{ppm}$ ).

The apparent activation energy varies from $0.4 \mathrm{eV}$ to $0.8 \mathrm{eV}$, depending on the methane concentration and on the cobalt amount. The lowest activation energies are obtained for $\mathrm{x}=1.8$, whatever the temperature and the $\mathrm{CH}_{4}$ concentration, indicating the reaction is easier for this composition. These values are in the range of those obtained when assuming a first order kinetic model for the combustion of methane [41], on various cobaltites.

The constant slopes obtained in Fig.9, where LnA is plotted versus the apparent activation energies, for the different samples and $\mathrm{CH}_{4}$ concentrations, indicate that basically, the nature of the active site is the same over the various samples [42]. The decrease of the activation energy is then linked to an increase in concentration of active sites in the different samples. The composition $\mathrm{x}=1.8$ is non stoechiometric, and the number of defects will be also higher than for the other tested compositions. These results indicate that the size effect 
governs the catalytic efficiency, but also that defects and vacancies play a role in the catalysis process.

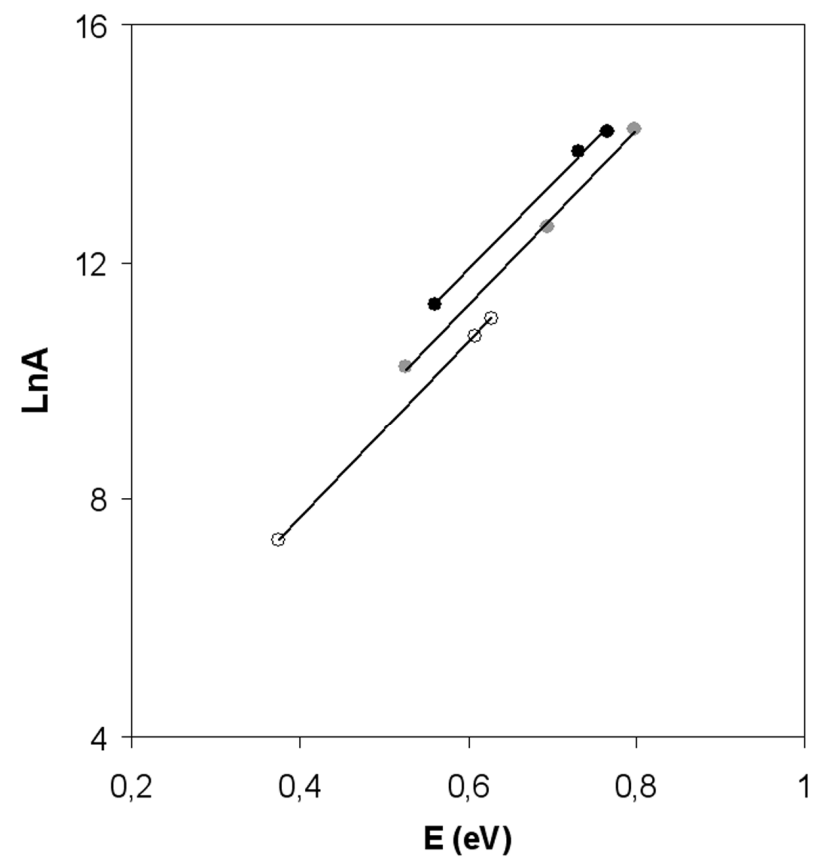

Figure 9 : plot of the pre exponential factor, LnA, versus the apparent activation energy, $E(\mathrm{eV})$, for the different samples ( $x=0.6, x=1, x=1.8)$ for various $\mathrm{CH}_{4}$ concentration (2500 ppm in black; $1250 \mathrm{ppm}$ in gray ; $625 \mathrm{ppm}$ in white)

Information about the kinetics of the conversion process can be found in the values of $\Delta \mathrm{t}$, the delay between the beginning of the reaction and the half constant conversion rate (see Table 5).

\begin{tabular}{lllll} 
& & \multicolumn{3}{c}{$\mathrm{CH}_{4}$ concentration (ppm) } \\
\hline $\mathrm{x}$ & $\mathrm{T}\left({ }^{\circ} \mathrm{C}\right)$ & \multicolumn{1}{c}{625} & \multicolumn{1}{c}{1250} & \multicolumn{1}{c}{2500} \\
\hline & & $\Delta \mathrm{t}(\mathrm{min})$ & $\Delta \mathrm{t}(\mathrm{min})$ & $\Delta \mathrm{t}(\mathrm{min})$ \\
\hline \multirow{3}{*}{0.6} & 400 & 5 & 3.5 & 6 \\
& 450 & 4 & 3 & 5.5 \\
& 500 & 4.5 & 3 & 3.5 \\
\hline \multirow{3}{*}{1} & 400 & 4 & 3.5 & 4 \\
& 450 & 4.5 & 3 & 3 \\
& 500 & 4.5 & 4 & 3 \\
\hline \multirow{3}{*}{1.8} & 400 & 4.5 & 3.5 & 5.5 \\
& 450 & 5 & 3 & 3 \\
& 500 & 5 & 3 & 2.5
\end{tabular}

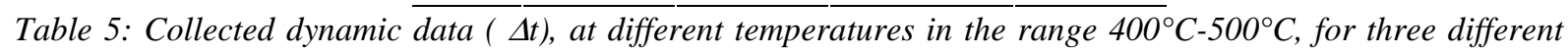
$\mathrm{CH}_{4}$ concentrations in air and for three different composition $x$ of the $\mathrm{Co}_{x} \mathrm{Fe}_{3-x} \mathrm{O}_{4}$ powders. 
For all the samples, temperatures, and $\mathrm{CH}_{4}$ concentrations, $\Delta \mathrm{t}$ values, are independent from the composition of the powders, and depend on the $\mathrm{CH}_{4}$ concentration and on temperatures. More precisely, $\Delta \mathrm{t}$ is independent of temperature for low and medium $\mathrm{CH}_{4}$ concentration, but decreases with temperature at high $\mathrm{CH}_{4}$ concentration. This indicates a change in the mechanisms governing the reaction for low $\mathrm{CH}_{4}$ and high $\mathrm{CH}_{4}$ concentration. This phenomenon was predicted in the case of the Langmuir- Hinshelwood mechanism [43]. This mechanism was evidenced already in mixed oxides, although it is more often associated to metal supported catalysts [44]. However, the experimental device we used to test the catalytic activity of the cobalt ferrites powder can only give some hints on the mechanism involved in the oxidation of methane.

\section{Conclusion}

Cobalt ferrites nanoparticles $\mathrm{Co}_{\mathrm{x}} \mathrm{Fe}_{3-\mathrm{x}} \mathrm{O}_{4}$ with various compositions $(\mathrm{x}=0.6, \mathrm{x}=1, \mathrm{x}=1.8)$, were obtained by a very simple non aqueous one pot process. These particles proved to be well dispersed, highly crystalline and chemically very homogeneous, even at the level of individual particles, and even for composition near $\mathrm{Co}_{2} \mathrm{FeO}_{4}$. Depending on the cobalt content, the size of the particles varied from $4 \mathrm{~nm}$ for high cobalt content up to $7.5 \mathrm{~nm}$ for low cobalt content. The shape of the nanoparticles was also influenced by the cobalt content, nearly spherical particles being obtained for low cobalt content, as for high cobalt content the shape of the particles was very irregular.

The catalytic tests showed that cobalt ferrite powders are valuable candidates for the combustion of methane. Among the different powders tested, $\mathrm{Co}_{1.8} \mathrm{Fe}_{1.2} \mathrm{O}_{4}$ has the most interesting behaviour, with low activation energies and high conversion rates. This can be related to the microstructure of this powder, composed of very small particles with irregular shapes and to the increase of active sites with the cobalt amount in $\mathrm{Co}_{\mathrm{x}} \mathrm{Fe}_{3-\mathrm{x}} \mathrm{O}_{4}$.

\section{Acknowledgements:}

The authors acknowledge the financial support of the France-Tunisia Cooperation Program (CMCU 06/S1309) 


\section{References}

[1] M. Sugimoto, J. Am. Ceram. Soc. 82 (1999) 269.

[2] A. Virden, S. Wells, K. O’Grady, J. Magn. Magn. Mater. 316 (2007) 768.

[3] D.S. Mathew, R.S. Juang, Chem. Eng. J. 129 (2007) 51.

[4] J.-C. Bacri, R. Perzynski, D. Salin, V. Cabuil, R. Massart, J. Magn. Magn. Mater. 62 (1986) 36.

[5] M. Pita, J.M. Abad, C. Vaz-Dominguez, C. Briones, E. Mateo-Marti, J.A. Martin-Gago, M. del Puerto Morales, V.M. Fernandez, J. Colloid Interface Sci. 321 (2008) 484.

[6] D.K. Kim, Y. Zhang, W. Voit, K.V. Rao, J. Kehr, B. Bjelke, M. Muhammed, Scr. Mater. 44 (2001) 1713.

[7] C.G. Ramankutty, S. Sugunan, Appl. Catal., A 218 (2001) 39.

[8] L.C.A. Oliveira, J.D. Fabris, R.R.V.A. Rios, W.N. Mussel, R.M. Lago, Appl. Cata. A 259 (2004) 253.

[9] D. Fino, N. Russo, G. Saracco, V. Specchia, J. Catal. 242 (2006) 38.

[10] M. Florea, M. Alifanti, V.I. Parulescu, D. Mihaila-Tarabasanu, L. Diamandescu, M. Feder, C. Negrila, L. Frunza, Catal. Today 141 (2009) 361.

[11] Q. Liu, L.C. Wang, M. Chen, Y. Cao, .H.Y. He, K.N. Fan, J. Catal. 263 (2009) 104.

[12] K. Madhusudan Reddy, L. Satyanarayana, S.V. Manorama, R.D.K. Misra, Mater. Res. Bull. 39 (2004) 1491.

[13] M.M. Raschad, O.A. Fouad, Mater. Chem. Phys. 94 (2005) 365.

[14] A. Mirzaei, R. Habibpour, M. Faizi, E. Kashi, Appl. Catal. A 301 (2006) 272.

[15] F. Bensebaa, F. Zavaliche, P. L'Ecuyer, R.W. Cochrane, T. Veres, J. Colloid Interface Sci. 277 (2004) 104.

[16] J. Wang, T. Deng, Y. Lin, C. Yang, W. Zhan, J. Alloys Compd. 450 (2008) 532.

[17] Z. Jiao, X. Geng, M. Wu, Y. Jiang, B. Zhao, Colloids Surf. A 313-314 (2008) 31.

[18] Y. Shi, J. Ding, H. Yin, J. Alloys Compd. 308 (2000) 290.

[19] L.J. Cote, A.S. Teja, A.P. Wilkinson, Z.J. Zhang, Fluid Phase Equilib. 210 (2003) 307.

[20] D. Zhao, X. Wu, H. Guan, E. Han, J. Supercritical Fluids 42 (2007) 226.

[21] R. Sani, A. Beitollahi, Y.V. Maksimov, I.P. Suzdalev, J. Mater. Sci. 42 (2007) 2126.

[22] C.-H. Yan, Z.-G. Xu, F.-X. Cheng, Z.-M. Wang, L.-D. Sun, C.-S. Liao, J.-T. Jia, Solid State Commun. 11 (1999) 287.

[23] N. Hanh, O.K. Quy, N.P. Thuy, L.D. Tung, L. Spinu, Phys. B 327 (2003) 382.

[24] J.-G. Lee, H.M. Lee, C.S. Kim, Y.-J. Oh, J. Magn. Magn. Mater. 177-181 (1998) 900.

[25] Ch.-S. Lee, D.-S. Bae, Mater. Forum .544-545 (2007) 865. 
[26] M.H. Khedr, A.A. Omar, S.A. Abdel - Moaty, Colloids Surf. A 281 (2006) 8.

[27] I.-H.Jung, S. A. Decterov, A. D. Pelton, H. -M. Jim, Y. -B. Kang, Acta Mat. 52 (2004) 507.

[28] N. Pinna, S. Grancharov, P. Beato, P. Bonville, M. Antonietti, M. Niederberger, Chem. Mater. 17 (2005) 3044.

[29] N.Pinna, M. Niederberger, Angew. Chem. 47 (2008) 5292

[30] M. Niederberger, G. Garnweitner, N.Pinna, M. Antonietti, J. Am. Chem. Soc. 126 (2004) 9120

[31] G. Baldi, D.Bonacchi, M. C. Franchini, D. Gentili, G. Lorenzi, A. Ricci, C. Ravagli, Langmuir 23 (2007) 4026

[32] M.-I. Baraton, L. Mehrari, Scripta Mat. 44 (2001) 1643.

[33] T.A.S. Ferreira, J.C. Waerenborgh, M.H.R.M. Mendonça, M.R. Nunes, F.M. Costa, Solid State Sci. 5 (2003) 383.

[34] H. Le Trong, A. Barnabe, L. Presmanes, Ph. Tailhades, Solid State Sci. 10 (2008) 550.

[35] D.H. Lee, H.S. Kim, J.Y. Lee, C.H. Yo, K.H. Kim, Solid State Commun. 96 (1995) 445.

[36] M.F.F. Lelis, A.O. Poro, C.M. Gonçalves, J.D. Fabris, J. Magn. Magn. Mater. 278 (2004) 263.

[37] J.-P. Jacobs, A. Maltha, G.H. Reintjes, J. Drimal, V. Ponec, H. H. Brongersma, J. Cat. 147 (1994) 294.

[38] L. Satyanarayana, K. Madhusudan Reddy, S.V. Manorama, Mater. Chem. Phys. 82 (2003) 21.

[39] D.Y. Murzin, Chem. Eng.Sci. 64 (2009) 1046.

[40] G. Evans, I.V. Kozhevnikov, E.F. Kozhevnikova, J.B. Claridge, R. Vaidhyanathan, C. Dickinson, C.D. Wood, A.I. Cooper, M.J. Rosseinsky, J. Mater. Chem. 18 (2008) 5518.

[41] M. Bosomoiu, G. Bozga, D. Berger, C. Matei, Appl. Catal. B 84 (2008) 758.

[42] G.A. El-Shobaky, A.M. Turky, N.Y.Mostafa, S.K. Mohamed, J. Alloys Compd. 493 (2010) 415

[43] H. Lynggaard, A. Andreasen, C. Stegelmann, P. Stoltze, Prog. Surf. Sci. 77 (2004) 71.

[44] S. Pengpanich, V. Meeyoo, T. Rirksomboon, K. Bunyakiat, Appl. Cat. A 234 (2002) 221. 